\section{Sivistys ihmisyyden ytimessä}

Wilenius, Reijo (1982/2021). Ihminen ja sivistys. Basam Books Oy. 84 sivua.

FILOSOFIAN PROFESSORI Reijo Wilenius kirjoitti teoksensa alkuaan vapaan sivistystyön aikuiskasvattajille pitämänsä luentosarjan pohjalta. Koska käsitys sivistyksestä muuttuu ajan mukana, on kiehtovaa lukea ajatuksia sivistyksestä neljän vuosikymmenen takaa ja peilata niitä nykypäivään.

Teos sukeltaa humanistisen sivistyskäsityksen ytimeen ja haastaa pohtimaan syviä filosofisia kysymyksiä esimerkiksi vastuusta, vapaudesta, työstä ja ihmisyydestä.

Kirjan julkaisun aikoihin, vuonna 1982 Wileniuksesta näytti, että koulutuksen sisällön muodostus oli ollut jo pitkään omiaan johtamaan "arvotietoisuuden autioitumiseen", ja sivistys oli työnnetty koulutuksen agendalla syrjään. Sivistyksen arvostus oli kuitenkin heräämässä uudelleen, jopa 'sivistys' sanana oli otettu taas käyttöön. Optimismi tuntuu hyvinkin ajankohtaiselta nyt, kun esimerkiksi Sitran Sivistys+-hankkeessa määritellään 'sivistystä' uudelleen.

Wileniuksen mukaan sivistyksellä on erityinen merkitys suomalaisille. Hän viittaa Fredrik Cygnaeuksen kirjeeseen Johan Vilhelm Snellmanille vuodelta 1840. Cygnaeus totesi, että Suomen historia oli joko sivistyshistoriaa tai se muuttuisi pelkäksi luonnonhistoriaksi. Suomi pystyisi lunastamaan paikkansa muiden kansojen joukossa vain henkisen laatunsa voimalla, josta se voisi antaa jotain maailmankulttuurille ja oikeuttaa itsenäisen olemassaolonsa. Wilenius kuvaakin, miten tärkeää sivistys on suomalaisille, jotka ovat olleet ahkeria lukijoita ja aikuiskoulutukseen osallistujia.

\section{MYÖTÄTUNTO VAATII MIELIKUVITUSTA}

Kirjassa on viisi lukua: "Mitä on ihminen", "Sivistyksen ulottuvuudet", "Yksilön elämänkulku kasvutapahtumana", "Sivistys ja vapaus" sekä "Työ ja sivistys". Aloituksesta piirtyvät kiinnostavasti esiin sivistyksen eri merkitykset eri aikakausina: siinä missä 1800-luku oli vahvaa kansallisvaltioiden ja niihin sidottujen identiteettien rakentamisen aikaa, vuonna 1982 sivistys merkitsi itsensä kehittämistä ja kulttuurin kuluttamista. Sittemmin Wileniuksen olettama suomalainen yhtenäiskulttuuri on moninaistunut, eikä enää voi esittää, että ”Linnan ja Päätalon tuotanto on Suomessa ehkä tärkeämpi sivistystekijä kuin kaikki valtakunnan yliopistot yhteensä”.

Wilenius perustaa sivistyksen tarkastelunsa antroposofi Rudolf Steinerin ihmistutkimukseen ja klassiseen sivistyskäsitykseen. Hän esittää sivistykselle kolme ulottuvuutta: totuudellisuus, esteettisyys ja eettisyys. Totuudellisuus ei tarkoita vain tietämistä

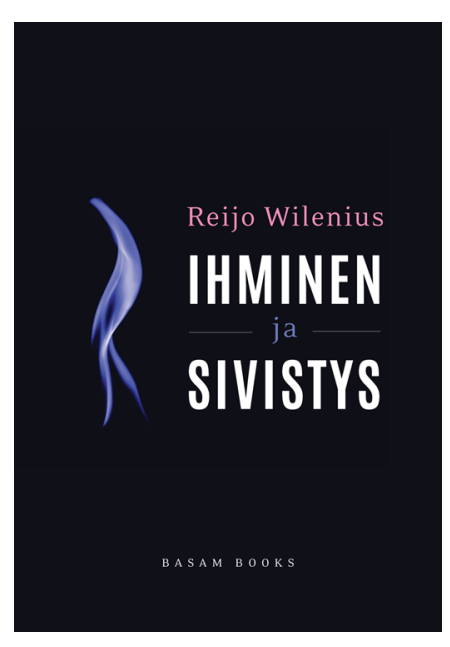

vaan myös "valmiutta jatkuvasti muuttaa käsityksiään", esimerkiksi uusien aatesuuntien kohtaamisessa tarvitaan joustavaa ja liikkuvaa ajattelua. Todellisuus on monitahoinen, eikä mikään näkökulma voi selittää sitä tyhjentävästi.

Voidakseen toimia myötätuntoisesti ja eettisesti ihmisen on kyettävä kuvittelemaan, miltä toisesta ihmisestä tuntuu. Tähän tarvitaan aistimisen, mielikuvituksen ja tuntemisen herkkyyttä eli esteettisyyttä, jota voidaan kehittää taidekasvatuksella. Eettisyyttä ei ole yksittäinen hyvä teko vaan tahdon suunta, motiivi pyrkiä hyvään. Sitä ei voi kasvattaa saarnaamalla vaan tosielämän tilanteita ja ristiriitoja ratkomalla yhdessä kasvatettavien kanssa.

Ajassamme puhuttelee Wileniuksen huomio siitä, että eettisen virikkeen syntymistä voidaan kasvatuksessa ja yhteiskunnassa käytännössä estää luomalla kilpailuasetelmia, kuten kilpailu arvosanoista, elintasosta tai voitosta. 


\section{TYÖ KIINNITTÄÄ}

\section{YHTEISKUNTAAN}

Wilenius määrittelee sivistyksen loputtomaksi prosessiksi. Sivistymätön ihminen voi olla rakka, röyhkeä, ylimielinen. Historia osoittaa lukemattomin esimerkein, miten tuhoava ihminen voi olla. Sivistys tarkoittaa Wileniukselle todellisuuteen juurtumista. Näin pyritään voittamaan vieraantumisen tunne suhteessa itseen, muihin ihmisiin ja luontoon. Kirjoittaja ei syvenny ekologisuuteen sen laajemmin, vaan tiivistää, että sivistyminen on ihmiselle välttämättömyys, josta riippuu ihmisarvoisen elämän jatkuminen maapallolla.

Keskustelu työn kautta muodostuvasta sivistyksestä kuuluu teoksen ajatuksia herättävimpiin lukuihin. Wilenius vaatii laajentamaan työn käsitettä palkkatyön ulkopuolelle, esimerkiksi vapaaehtoistoimintaan tai kulttuurin alalle: "[t]yötä on säännöllinen, sosiaalisesti mielekäs toiminta, jossa yksilö käyttää, ylläpitää ja kehittää kykyjään”. Toimeentulon lisäksi työllä on sosiaalinen ja henkinen ulottuvuutensa. Itsensä tarpeelliseksi kokeminen ja työn kautta yhteiskuntaan jäsentyminen on tärkein yhteiskunnallisen osallistumisen muoto. Kotityön merkitystä kirjoittaja ei kuitenkaan mainitse.

Työttömyys ja B-luokan kansalaisuus voivat aiheuttaa vieraantumista, kun tarjotaan koulutusta ja julkisen vallan toimenpiteitä, "mutta ei kasvatusta tai työtä". Wilenius arvostelee 1970-luvulla levinnyttä koulutusputkiajattelua ja puolustaa yleissivistävää, ihmisen persoonallisuutta kehittävää otetta kasvatukseen. Laaja-alainen koulutus vastaisi paremmin työtehtävien muutokseen ja turvaisi näin työllisyyttä. Samantyyppistä keskustelua käydään edelleen, kun esimerkiksi pohditaan ammatillisen koulutuksen ja korkeakoulutuksen tutkintojen sisältöä.

\section{HUOLI KOULUTUKSEN KAVENTUMISESTA}

Wilenius käsittelee sivistyksen ulottuvuuksia tavalla, joka tekee kirjasta monella tapaa ajattoman: "Jokaisen ajan on luotava oma sivistyskäsityksensä ja -käytäntönsä," hän kirjoittaa. Jäsennyksillään hän tarjoaa sivistyskeskusteluun edelleen käyttökelpoisia työkaluja.

Ajassamme yhä tunnistettavia kehityskulkuja on ainakin huoli koulutuksen kaventumisesta käytännöllisten tietojen ja osaamisen kartuttamiseksi. Samoin työn moninaisten merkitysten pohtiminen tuntuu edistykselliseltä ja edelleen tärkeältä. Wileniuksen ajatuksiin soisi palattavan sekä yhteiskunnallisessa keskustelussa että työllisyys- ja koulutuspolitiikan muotoilussa.

Sivistyksen käsittäminen yksilökeskeisesti tuntuu kapealta, kuten Kriittisen korkeakoulun toiminnanjohtaja Eero Ojanen teoksen uudistetun painoksen jälkisanoissa toteaa. Uusi sivistysajattelu ei perustu ensisijaisesti yksilön henkisiin kehitystarpeisiin vaan kestävään ja yhä oikeudenmukaisempaan maailmaan pyrki- miseen. Ympäristökysymyksistä puhuttiin 1980-luvulla vähemmän kuin nykyisin. On silti kiinnostavaa, miten vähän sivistyksen ekologista vastuuta teoksessa käsitellään - varsinkin, kun Ojanen kirjoittaa Wileniuksen tuoneen maapallon rajoihin perustuvaa talouskasvun kritiikkiä Suomeen jo 1960-luvulla.

Moni aikuiskasvatuksen toimija voinee yhtyä Wileniuksen kehotukseen elvyttää sivistyksen aatetta. Sivistysliikehdintä onkin jälleen noussut monella rintamalla: eri tahot ovat tunnistaneet tarpeen löytää yhä moniäänisempiä sivistyksen tavoitteita, ja puhutaan globaalista tai planetaarisesta sivistyksestä. Samaan keskusteluun kuuluu aiempien sivistyskäsitysten tarkasteleminen kriittisesti feministisistä tai jälkikolonialisista näkökulmista.

Wilenius ei tuo keskusteluun valtakysymystä: kenellä on ylipäänsä mahdollisuus sivistyä? Hän toteaa kuitenkin, että sivistys on kykyä lähestyä yhteiskunnallisia ongelmia eri kannoilta, eläytyä vieraisiin katsomustapoihin ja valmiutta muuttaa omia käsityksiä. Muuttuvassa maailmassa tälle ajatukselle on yhä enemmän tarvetta.

\section{RIIKKA SUHONEN}

FM, väitöskirjatutkija Helsingin yliopisto

(iD https://orcid.org/0000-00016167-6352

\section{NINA HJELT}

KM, projektipäällikkö

Kvs-säätiö (Kansanvalistusseura sr.) 